\title{
Association of SP-D, MBL and I-NOS genetic variants with pulmonary tuberculosis
}

\author{
Mudit Vaid, Savneet Kaur, Madan Taruna, Hari Singh*, Vijay K. Gupta*, K. J. R. Murthy**, Puranam U. Sarma \\ Molecular Biochemistry and Diagnostics, Institute of Genomics and Integrative Biology, Mall Road, Delhi, *Department of Biochemistry, \\ Kurukshetra University, Kurukshetra, ${ }^{* *}$ Mahavir Medical Research Centre, Mahavir Hospital, Hyderabad, India
}

BACKGROUND: Pulmonary tuberculosis is caused by Mycobacterium tuberculosis. It is a multifactorial disease with both host as well as pathogen factors contributing to susceptibility and protection from the disease. Various reports have highlighted important roles of lung surfactant protein $D$ (SP-D), mannan-binding lectin (MBL) and I-NOS in innate immune defense against $M$. tuberculosis

AIMS: The present study investigated the role of polymorphisms in three candidate genes encoding Lung surfactant protein D, Mannan binding lectin and Inducible Nitric oxide synthase, in susceptibility and protection to pulmonary tuberculosis.

SETTINGS AND DESIGN: A case-control association study of SNP's in lung surfactant protein D (SP-D), mannanbinding lectin (MBL) and I-NOS with pulmonary tuberculosis in Indian population was carried out. This involved sequencing of all the coding exons of lung surfactant protein D (SP-D), while, exon 1 (collagen region) and exon 4 (carbohydrate recognition domain) of mannan-binding lectin (MBL) and exons 2, 8 and 16 of I-NOS and their flanking intronic regions for single nucleotide polymorphisms in DNA samples isolated from 30 pulmonary tuberculosis patients and 30 controls of Indian population.

STATISTICAL ANALYSIS: Various allele frequencies were calculated using online two by two table (home.clara.net/ sisa/). Odds ratio and $P$ values were calculated at $95 \%$ confidence interval $(\mathrm{Cl})$.

RESULTS: A total of fourteen single nucleotide polymorphisms (5 in SP-D, 5 in MBL and 4 in l-NOS) were observed of which four (G459A SP-D, G274T I-NOS, G1011A and T357G MBL) have not been reported earlier. Four single nucleotide polymorphisms viz. G459A of exon 7 of SP-D $(P=0.00$, odds ratio $(O R)=4.96$, $2.18<\mathrm{OR}<11.31), \mathrm{G} 875 \mathrm{~A}$ of exon 1 of $\mathrm{MBL}(P=0.00$ or $=$ $3.851 .66<\mathrm{OR}<8.88)$, G300A of intron $8(P=0.00$ or $=4.04$ $2.20<\mathrm{OR}<7.42)$ and $\mathrm{G} 274 \mathrm{~T}$ of intron 16 of I-NOS $(P=0.00$ or $=4.46,2.40<\mathrm{OR}<8.28)$ showed significant association with TB in Indian population.

CONCLUSION: The present study has led to identification of 4 SNP's in SP-D, MBL and I-NOS associated with pulmonary tuberculosis in Indian population.

Key words: Inducible nitric oxide synthase, lung surfactant protein D, mannan binding lectin, polymorphism, pulmonary tuberculosis

\section{Introduction}

M. tuberculosis is a ubiquitous pathogen: estimates are that roughly one third of the world's population is infected with the bacillus and it is responsible for eight to 12 million cases of active tuberculosis each year and three million deaths. ${ }^{[1]}$ There is compelling clinical evidence that, cross-talk between bacterial pathogenicity and host immune response against $M$. tuberculosis determines the clinical manifestations and ultimate outcome of the infection. ${ }^{[2,3]}$

Collectins such as, lung surfactant proteins and mannan-binding lectin (MBL) have evolved as key players of innate immunity against various pathogens, ${ }^{[4-8]}$ including mycobacterium. Several studies suggest an opsonic role for lung surfactant protein $A$ and $M B L$ against mycobacterium. ${ }^{[9-11]}$ However there are conflicting reports regarding role of Lung surfactant protein D (SP-D) in mycobacterial opsonization. ${ }^{[12,13]}$ Suggesting a modulatory role for SP-D in mycobacterial phagocytosis, with exact role of SP-D still evading.

Besides binding and opsonization, a role of macrophage activation has also been assigned to the collectins which leads to enhanced phagocytosis and killing of mycobacteria through a concerted activity of IFN- $\gamma$ and TNF- $\alpha$ which operates through participation of reactive oxygen intermediates (ROI) and reactive nitrogen intermediates (RNI). ${ }^{[14]} \mathrm{RNI}$ and especially $\mathrm{NO}$ have been implicated as important defense molecules against mycobacteria. ${ }^{[15-17]}$ Out of two NO producing enzymes namely inducible and constitutive (endothelial and neuronal) nitric oxide synthases, NO produced by inducible nitric oxide synthase (I-NOS) is relevant for 
innate immunity against pathogens.

Since, the incidence of $T B$ is higher in immunocompromised individuals, ${ }^{[18,19]}$ studies on innate immune factors are of particular significance. We believe that the long arm of Chromosome 10 which houses SP$A, S P-D$ and $M B L$ in close proximity is an ideal candidate region for screening genetic factors associated with tuberculosis. In our earlier studies, we observed association of polymorphisms of SP-A2 with pulmonary tuberculosis in Indian population. ${ }^{[20]}$ The association of $S P-D$ polymorphisms with TB has been reported in Mexican population. ${ }^{[21]}$ In case of MBL, there are conflicting reports regarding association of ' $\mathrm{B}$ ' allele of $M B L$ (codon 54 polymorphism in exon 1, coding for low serum MBL levels), with pulmonary tuberculosis in different populations. ${ }^{[22-26]}$ The 17q11-q21 region, housing I-NOS gene, was mapped as susceptibility locus for tuberculosis in Brazilians. ${ }^{[27]}$

So in the present report, we have carried out casecontrol association studies of SNP's in SP-D, MBL and I-NOS with pulmonary tuberculosis in Indian population. This involved sequencing of all the coding exons of $S P$ $D$, while, exon 1 (collagen region) and exon 4 (carbohydrate recognition domain) of $M B L$ and exons 2, 8 and 16 of $I-N O S$ and their flanking intronic regions for single nucleotide polymorphisms since these regions have been shown to be functionally important in earlier studies.

\section{Materials and Methods}

\section{Study design}

Following approval of the Institute's Human Ethics Committee, SNP screening of coding exons and flanking intronic regions of SP-D, MBL and I-NOS was carried out in Indian subjects. The study comprised of group of 30 patients of pulmonary tuberculosis enrolled at the Mahavir Medical Research Center, Mahavir hospital, Hyderabad, India. Diagnosis of TB was based on demonstration of acid-fast bacilli (AFB) in sputum and was eventually confirmed by positive culture of Mycobacterium tuberculosis. A second group of 30 healthy, tuberculin non-reactors, age and sex matched to patients was taken as the control.

\section{Genomic DNA isolation}

Human genomic DNA was isolated from blood using modified salting out procedure. ${ }^{[28]}$ Briefly nuclei were isolated from $10 \mathrm{ml}$ blood (collected in ACD) by addition of ice-cold cell lysis buffer to the blood followed by centrifugation at $3100 \mathrm{rpm}$ for 15 minutes. To the pelleted nuclei then added $12 \mathrm{ml}$ of nucleus lysis buffer, $0.8 \mathrm{ml}$ of $10 \% \mathrm{SDS}$ and $50 \mathrm{uL}$ of proteinase $\mathrm{K}(20 \mathrm{mg} / \mathrm{ml})$. Proteins were then precipitated using $4 \mathrm{ml}$ of $6 \mathrm{M} \mathrm{NaCl}$ and finally pelleted by spinning at $2500 \mathrm{rpm}$ for 15 minutes. To the supernatant added exactly two volumes of room temperature $100 \%$ ethanol and inverted the tube several times until the DNA precipitate is visible, which was then removed with a plastic spatula or pipette tip and transferred to an eppendorf tube containing 100-200 $\mu \mathrm{l}$ TE.

\section{Polymerase chain reaction (PCR)}

All PCR amplification reactions used $50 \mathrm{ng}$ of the template DNA, $1.5 \mathrm{mM} \mathrm{MgCl}_{2}, 0.2 \mathrm{mM}$ dNTP (Amersham, UK), 1.5 units of Taq polymerase (Bangalore genei, India) and 20.0 pico mole each of forward and reverse primers, in $50 \mu \mathrm{L}$ of reaction. Primers for Exon 2 of I-NOS were taken from previous report ${ }^{[29]}$ while Table 1 summarizes the sequence and amplification conditions for other primers used in the present study.

\section{Purification of the PCR products}

PCR products were purified by PEG-8000/Sodium acetate (3M, ph 4.8) precipitation except in the case of exons 1 and 4 of SP-D where purification was carried out using DNA elution Kit (Cat no. 20-200-300, Biological Industries) as per manufacturer's instructions. Purified samples were air dried and resuspended in $10 \mu \mathrm{L}$ of autoclaved MilliQ water and quantitated on $1 \%$ agarose gel.

\section{Cycle sequencing}

Purified PCR products thus obtained were subjected to cycle sequencing reaction based on dideoxy termination reaction. Briefly $35-50 \mathrm{ng}$ of the purified PCR product was amplified using 1 pico mole of the forward primer and $4.0 \mu \mathrm{L}$ of ready reaction mix in a $10 \mu \mathrm{L}$ 
Table 1: Primer list

\begin{tabular}{|c|c|c|}
\hline $\begin{array}{l}\text { Region/Gene } \\
\text { (NCBI acc. No.) }\end{array}$ & Primer sequence & $\begin{array}{l}\text { Amplification } \\
\text { conditions }\end{array}$ \\
\hline \multirow[t]{2}{*}{ Exon $1 S P-D$ (L05483) } & FP-5'TGAGCCAAGTCCCTAAACCAT 3' & 35 cycles \\
\hline & RP-5'CTCTCCCATCCCGTCCATC3' & $95^{\circ} \mathrm{C}$ for $45^{\prime \prime} 63.5^{\circ} \mathrm{C}$ for \\
\hline \multirow[t]{2}{*}{ Exon 2, 3 SP-D (L05484) } & FP-5'GGGTCTAGGGCCAGGTCTTTGTC3' & $45^{\prime \prime} 72^{\circ} \mathrm{C}$ for $45^{\prime \prime}$ \\
\hline & RP-5'GCTTGCCCTGAGGTCCTATGTTCC3' & 30 cycles $95^{\circ} \mathrm{C}$ for $30^{\prime \prime} 61^{\circ} \mathrm{C}$ for \\
\hline Exon 4 SP-D (L05484) & FP-5'AGGAGCGGCAGAAAGCAAGGAGA3' & $1^{\prime} 72^{\circ} \mathrm{C}$ for $1^{\prime}$ \\
\hline \multirow[t]{2}{*}{ Exon $5 S P-D$ (L05484) } & FP-5’GTTGGGTGGCGGGCAGTTT3’' & $45^{\prime \prime} 72^{\circ} \mathrm{C}$ for $45^{\prime \prime}$ \\
\hline & RP-5'TGAATTGGGAAGGCGAGTTGTAGT3' & 35 cycles $95^{\circ} \mathrm{C}$ for $45^{\prime \prime} 58^{\circ} \mathrm{C}$ for \\
\hline \multirow[t]{2}{*}{ Exon 6 SP-D (L05484) } & FP-5’GTCTTTACTTGGCCTTTTTCTCC3’ & $45^{\prime \prime} 72^{\circ} \mathrm{C}$ for $45^{\prime \prime}$ \\
\hline & RP-5'GGTCCCAGCTCATTCCCATCCTA3' & 35 cycles $95^{\circ} \mathrm{C}$ for $45^{\prime \prime} 58^{\circ} \mathrm{C}$ for \\
\hline Exon 7 SP-D (L05485) & FP-5'CATCTGTAAGTGGGGAATCAT3' & $45^{\prime \prime} 72^{\circ} \mathrm{C}$ for $45^{\prime \prime}$ \\
\hline \multirow[t]{2}{*}{ Exon 16 I-NOS (X85772) } & FP-5'CCCCCTTCTGGTCCTCTCC3' & $45^{\prime \prime} 72^{\circ} \mathrm{C}$ for $45^{\prime \prime}$ \\
\hline & RP-5'AGCCCCATATGTAAACCAACTTCCЗ & 35 cycles $95^{\circ} \mathrm{C}$ for $45^{\prime \prime} 58^{\circ} \mathrm{C}$ for \\
\hline \multirow[t]{2}{*}{ Exon $1 \mathrm{MBL}$ (AF080508) } & FP- 5'TGC ACC CAG ATT GTA GGA C 3' & $45^{\prime \prime} 72^{\circ} \mathrm{C}$ for $45^{\prime \prime}$ \\
\hline & RP- 5'AGC TGA ATC TCT GTT TTG A 3' & 25 cycles $95^{\circ} \mathrm{C}$ for $45^{\prime \prime} 52^{\circ} \mathrm{C}$ for \\
\hline \multirow[t]{2}{*}{ Exon $4 \mathrm{MBL}(\mathrm{X} 15957)$} & FP-5'ATT TTA TCC GGC AAC TCT ACT CTA3 & $45^{\prime \prime} 72^{\circ} \mathrm{C}$ for $45^{\prime \prime}$ \\
\hline & RP-5' TGC CCA CAA AAG GAA CAA T 3' & $\begin{array}{l}25 \text { cycles } 95^{\circ} \mathrm{C} \text { for } 45^{\prime \prime} 58.5^{\circ} \mathrm{C} \text { for } \\
1^{\prime} 72^{\circ} \mathrm{C} \text { for } 45^{\prime \prime}\end{array}$ \\
\hline
\end{tabular}

(All amplification reactions consisted of initial denaturation at $95^{\circ} \mathrm{C}$ for $2^{\prime}$, final extension at $72^{\circ} \mathrm{C}$ for $4^{\prime}$ )

reaction. Autoclaved MilliQ water was used to make up the volume wherever required. Amplified product was precipitated using $150 \mathrm{mM}$ EDTA and 3M NaOAc followed by two $70 \%$ ethanol washes and air-dried. Samples were loaded on capillary-based ABI 3730 sequencer as per the standard procedures. Cycle sequencing program consisted of 25 cycles of denaturation at $96^{\circ} \mathrm{C}$ for 10 seconds, annealing at $50^{\circ} \mathrm{C}$ for five seconds, extension at $60^{\circ} \mathrm{C}$ for four minutes and final incubation at $4^{\circ} \mathrm{C}$. Sequence data obtained was analyzed for the polymorphisms using basic local alignment search tool (http://www.ncbi.nlm.nih.gov/ BLAST/) and Seqman software of DNA star.

\section{Statistical analysis}

Statistical analysis and frequencies of various alleles were calculated using online two by two table (home.clara.net/sisa/). Odds ratio and $P$ values were calculated at $95 \%$ confidence interval $(\mathrm{Cl})$.

\section{Results}

In the present study we screened polymorphisms in all the coding exons of $S P-D$, exons 1 and 4 (encoding collagen and CRD region respectively) of $M B L$ and exons 2, 8 and 16 of I-NOS and investigated the role of these polymorphisms in genetic predisposition to pulmonary tuberculosis in Indian population. We found that at a number of places (21 in SP-D, 25 in I-NOS and 1 in $M B L$ ) the observed sequence did not match the sequence reported in the database. We have assigned them as changes [data not shown] and not polymorphisms as these changes were observed in all the samples analyzed in the study irrespective of their health status. Interestingly, all but three (2 in SP-D and 1 in $\mathrm{MBL}$ ) changes were intronic.

A total of fourteen single nucleotide polymorphisms (Table 2; 5 in SP-D, 5 in MBL and 4 in l-NOS) were observed in the present study. To the best of our knowledge four of these SNP's (G459A SP-D, G274T INOS, G1011A and T357G MBL) have not been reported earlier. A comparison of allele frequencies between controls and TB patients [Table 3] revealed that ' $A$ ' allele at position G459A of exon 7 of $S P-D(P=0.00$ or $=4.96$; $2.18<\mathrm{OR}<11.31$ ) was significantly associated with $\mathrm{TB}$ in Indian population. Interestingly, none of the subjects screened was homozygous for ' $A$ ' allele.

The mutant 'A' allele of G875A in codon 54 of $M B L$ 
Table 2: List of single nucleotide polymorphisms observed in SP-D, I-NOS and MBL in the Indian population

\begin{tabular}{|c|c|c|c|c|}
\hline NCBI acc. No. & Position & Region & Nature & Amino acid change \\
\hline \multicolumn{5}{|l|}{ SP-D } \\
\hline L05483 & 341 & Exon 1 & $\mathrm{C} / \mathrm{T}$ & Thr 31 Met \\
\hline LO5484 & 1749 & Exon 4 & $\mathrm{G} / \mathrm{A}$ & Ala $180 \mathrm{Thr}$ \\
\hline \multirow[t]{3}{*}{ L05485 } & 174 & Intron 6 & $\mathrm{~T} / \mathrm{C}$ & - \\
\hline & 456 & Exon 7 & $\mathrm{~T} / \mathrm{C}$ & Ala 306 Ala \\
\hline & 459 & Exon 7 & $\mathrm{G} / \mathrm{A}$ & Lys 307 Lys \\
\hline \multicolumn{5}{|l|}{ I-NOS } \\
\hline $\mathrm{X} 85760$ & 166 & Exon 2 (5' UTR) & $\mathrm{C} / \mathrm{T}$ & - \\
\hline$X 85766$ & 300 & Intron & $\mathrm{G} / \mathrm{A}$ & - \\
\hline \multirow[t]{2}{*}{ X85772 } & 150 & Exon 16 & $\mathrm{C} / \mathrm{T}$ & Ser 608 Leu \\
\hline & 274 & Intron & $\mathrm{G} / \mathrm{T}$ & \\
\hline \multicolumn{5}{|l|}{ MBL } \\
\hline AF080508 & 868 & Exon 1 & $\mathrm{C} / \mathrm{T}$ & Arg 52 Cys \\
\hline AF080508 & 875 & Exon 1 & $G / A$ & Gly 54 Asp \\
\hline AF080508 & 884 & Exon 1 & $G / A$ & Gly 57 Glu \\
\hline AF080508 & 1011 & Intron 1 & $\mathrm{G} / \mathrm{A}$ & - \\
\hline X15957 & 357 & Exon 4 & $T / G$ & Val 151 Gly \\
\hline
\end{tabular}

Table 3: Statistical evaluation of allele frequencies observed in SP-D, I-NOS and MBL

\begin{tabular}{lcccc}
\hline Gene/polymorphism & \multicolumn{2}{c}{ Allele frequencies } & & TB vs. Controls \\
\hline SP-D G459A & TB patients (\%) & Controls (\%) & P-value & Odd's ratio (95\%Cl) \\
G & $22(68.7)$ & $33(91.6)$ & 0.00 & 4.96 \\
A & $10(31.3)$ & $3(8.4)$ & & $2.18<\mathrm{OR}<11.31$ \\
I-NOS G300A & $26(76.4)$ & $16(44.4)$ & & 4.04 \\
G & $8(23.6)$ & $20(55.5)$ & 0.00 & $2.20<\mathrm{OR}<7.42$ \\
A & $18(45)$ & $33(78.5)$ & 0.00 & 4.46 \\
I-NOS G274T & $22(55)$ & $9(21.5)$ & & $2.40<\mathrm{OR}<8.28$ \\
G & $34(73.9)$ & $44(91.6)$ & 0.02 & 3.85 \\
T & $12(26.1)$ & $4(8.4)$ & & $1.66<\mathrm{OR}<8.88$ \\
MBL G875A & & & & \\
G & & & \\
A & & & & \\
\hline
\end{tabular}

exon $1(P=0.00$ or $=3.851 .66<\mathrm{OR}<8.88)$ showed significant association with TB in the Indian population. The frequency of mutant allele of MBL codon 57 ('A' allele of G884A), was similar in patients and controls while mutant allele for $M B L$ codon 52 (' $T$ ' allele of C868T), was observed only in one of the controls. The novel SNP T357G in codon 151 of MBL exon 4 involved a change from Valine to Glycine. However, the frequency of mutant ' $G$ ' allele of T357G was similar in patients and controls and hence showed no association with the disease. The genotype analysis showed that two patients were homozygous for ' $A$ ' allele of codon 54 polymorphism, while none of the controls were homozygous, whereas we didn't detect the presence of any functional mutant homozygote of other SNPs in exon 1 and exon 4 of $M B L$.

In I-NOS, G allele at position G300A of intron 8 $(P=0.00$ or $=4.04,2.20<\mathrm{OR}<7.42)$ is associated with tuberculosis with frequency of homozygous 'GG' patients almost 2.5 times that of homozygous controls. T allele at position G274T of intron 16 of $I-N O S$ ( $P=0.00$ or= $4.46,2.40<\mathrm{OR}<8.28)$ showed significant association with pulmonary TB in Indian population [Table 3]. Genotype patterns for patients and controls w.r.t. G274T revealed that none of the controls were homozygous for the mutant ' $T$ ' allele, whereas five out of 20 (25\%) patients showed homozygosity for this allele.

\section{Discussion}

Association of TB with alleles of various genes like vitamin $D$ receptor, interferon-gamma, mannose-binding lectin, IL-1 and NRAMP etc, suggest it to be a multifactorial disorder with various host genetic factors regulating susceptibility and/or protection against the disease. ${ }^{[30-36]}$

'A' allele at position G459A of exon 7 of SP-D was found to be significantly associated with TB in Indian population. This is a novel but synonymous 
polymorphism, with both the alleles coding for lysine. Because of the polygenic nature of $T B$, there is a possibility of A allele of G459A being in linkage disequlibrium with some other important genetic factors. Earlier Floros et al have identified DA11_C in exon 1 of $S P-D$ as susceptibility locus for tuberculosis in Mexican population. ${ }^{[21]}$ This polymorphism was not observed in the present study. Further our data on genetic polymorphisms in $S P-D$ in Indian population suggests that $S P-D$, unlike $S P-A$, is highly conserved.

In case of $M B L$, a significant association of ' $\mathrm{B}$ ' allele with tuberculosis is similar to the earlier observations made by Selvaraj et al in Indian population. ${ }^{[22]} \mathrm{A}$ similar observation in African-Americans has also been reported. [23] MBL forms the humoral mediator of mycobacterial phagocytosis and a reduction in the levels of functional $\mathrm{MBL}$ in the serum caused by the presence of variant alleles of MBL may affect the initial defense against $M$. tuberculosis It has been suggested that the presence of 'B' allele, which leads to low levels of MBL in the serum, might affect the antigen presentation by macrophages and antigen recognition by lymphocytes, which may lead to decreased lymphocyte response $M$. tuberculosis antigen. ${ }^{[24]}$ However our observations are not in coherence with those of Soborg et al in Caucasians $^{[25]}$ and Ozbas et al in Turks. ${ }^{[26]}$

Sequencing of I-NOS revealed that susceptibility to infection is associated with two intronic SNP's in I-NOS namely G300A (intron 8) and G274T (intron 16). Since G300A is only 12 bases downstream of exon 8 - intron 8 boundary, a site for alternative splicing ${ }^{[29]}$ it may be affecting the splicing. C166T polymorphism in exon 2 (coding 5'UTR) and C150T, a nonsynonymous exonic polymorphism (Ser to Leu) in exon 16 of I-NOS already reported in the Danish population, ${ }^{[29]}$ were observed in the Indian population but did not show association with pulmonary tuberculosis in the Indian population.

The present study has led to identification of 4 SNP's in $S P-D, M B L$ and I-NOS associated with pulmonary tuberculosis in the Indian population and has enriched the already known list of genetic markers for predictive diagnosis of tuberculosis.

\section{Acknowledgments}

This work was supported by the Council for Scientific and
Industrial Research (T.M, P.U.S.) (CMM0016). We acknowledge the technical expertise provided by The Center for Genomic application (TCGA), a collaborative effort of the Institute of Genomics and Integrative Biology, (a CSIR organization), supported by DST and Institute of Molecular Medicine (a Chatterjee Group company) for the sequencing of PCR products. Mudit Vaid and Savneet Kaur are recipients of Senior Research Fellowships, Council of Scientific and Industrial Research.

\section{References}

1. Raviglione MC, Snider DE Jr, Kochi A. Global epidemiology of tuberculosis. Morbidity and mortality of a worldwide epidemic. JAMA 1995;273:220-6.

2. Smith I. Mycobacterium tuberculosis pathogenesis and molecular determinants of virulence. Clin Microbiol Rev 2003;16:463-96.

3. Colakoglu S. Mycobacterium tuberculosis virulence factors and its immune evasion mechanisms. Mikrobiyol Bul 2004;38:155-67.

4. Eggleton P, Reid KB. Lung surfactant proteins involved in innate immunity. Curr Opin Immunol 1999;11:28-33.

5. Wu H, Kuzmenko A, Wan S, Schaffer L, Weiss A, Fisher $\mathrm{JH}$, et al. Surfactant proteins $A$ and $D$ inhibit the growth of Gram-negative bacteria by increasing membrane permeability. J Clin Invest 2003;111:1589-602.

6. Kishor U, Madan T, Sarma PU, Singh M, Urban BC, Reid KB. Protective roles of pulmonary surfactant proteins, SP$A$ and SP-D, against lung allergy and infection caused by Aspergillus fumigatus. Immunobiology 2002;205:610-8.

7. Oberley RE, Goss KL, Ault KA, Crouch EC, Snyder JM. Surfactant protein $D$ is present in the human female reproductive tract and inhibits Chlamydia trachomatis infection. Mol Hum Reprod 2004;10:861-70.

8. Bourbon JR, Chailley-Heu B. Surfactant proteins in the digestive tract, mesentery and other organs: Evolutionary significance. Comp Biochem Physiol A Mol Integr Physiol 2001;129:151-61.

9. Pasula R, Downing JF, Wright JR, Kachel DL, Davis TE $\mathrm{Jr}$, Martin WJ $2^{\text {nd }}$. Surfactant protein A (SP-A) mediates attachment of Mycobacterium tuberculosis to murine alveolar macrophages. Am J Respir Cell Mol Biol 1997;17:209-17.

10. Gaynor CD, McCormack FX, Voelker DR, McGowan SE, Schlesinger LS. Pulmonary surfactant protein A mediates enhanced phagocytosis of Mycobacterium tuberculosis by a direct interaction with human macrophages. J Immunol 1995;155:5343-51.

11. Polotsky VY, Belisle JT, Mikusova K, Ezekowitz RA, Joiner $\mathrm{KA}$. Interaction of human mannose-binding protein with Mycobacterium avium. J Infect Dis 1997;175:1159-68.

12. Kudo K, Sano H, Takahashi H, Kuronuma K, Yokota S, Fujii N, et al. Pulmonary collectins enhance phagocytosis of Mycobacterium avium through increased activity of mannose receptor. J Immunol 2004;172:7592-602.

13. Ferguson JS, Voelker DR, McCormack FX, Schlesinger LS. Surfactant protein D binds to Mycobacterium tuberculosis bacilli and lipoarabinomannan via carbohydrate-lectin interactions resulting in reduced phagocytosis of the bacteria by macrophages. J Immunol 1999;163:312-21.

14. Weikert LF, Lopez JP, Abdolrasulnia R, Chroneos ZC, Shepherd VL. Surfactant protein A enhances mycobacterial killing by rat macrophages through a nitric oxide- 
dependent pathway. Am J Physiol Lung Cell Mol Physiol 2000;279:L216-23.

15. Wang $\mathrm{CH}$, Liu CY, Lin HC, Yu CT, Chung KF, Kuo HP. Increased exhaled nitric oxide in active pulmonary tuberculosis due to inducible NO synthase upregulation in alveolar macrophages. Eur Respir J 1998;11:809-15.

16. Wang $\mathrm{CH}$, Lin HC, Liu CY, Huang $\mathrm{KH}$, Huang TT, Yu CT, et al. Upregulation of inducible nitric oxide synthase and cytokine secretion in peripheral blood monocytes from pulmonary tuberculosis patients. Int $\mathrm{J}$ Tuberc Lung Dis 2001;5:283-91.

17. Rich EA, Torres M, Sada E, Finegan CK, Hamilton BD, Toossi Z. Mycobacterium tuberculosis (MTB)-stimulated production of nitric oxide by human alveolar macrophages and relationship of nitric oxide production to growth inhibition of MTB. Tuber Lung Dis 1997;78:247-55.

18. Yamada H, Nakahara Y, Aoki Y, Katoh O, Hiura K, Kuroki $\mathrm{S}$, et al. Hospital-onset tuberculosis in compromised host. Intern Med 1992;31:740-5.

19. Billy C, Perronne C. Immunodeficiency and tuberculosis. Rev Prat 2002;52:2139-43.

20. Madan T, Saxena S, Murthy KJ, Muralidhar K, Sarma PU. Association of polymorphisms in the collagen region of human $S P-A 1$ and SP-A2 genes with pulmonary tuberculosis in Indian population. Clin Chem Lab Med 2002;40:1002-8.

21. Floros J, Lin HM, Garcia A, Salazar MA, Guo X, DiAngelo $S$, et al. Surfactant protein genetic marker alleles identify a subgroup of tuberculosis in a Mexican population. $J$ Infect Dis 2000;182:1473-8.

22. Selvaraj P, Narayanan PR, Reetha AM. Association of functional mutant homozygotes of the mannose binding protein gene with susceptibility to pulmonary tuberculosis in India. Tuber Lung Dis 1999;79:221-7.

23. EI Sahly HM, Reich RA, Dou SJ, Musser JM, Graviss EA. The effect of mannose binding lectin gene polymorphisms on susceptibility to tuberculosis in different ethnic groups. Scand J Infect Dis 2004;36:106-8.

24. Selvaraj P, Kurian SM, Uma H, Reetha AM, Narayanan $\mathrm{PR}$. Influence of non-MHC genes on lymphocyte response to Mycobacterium tuberculosis antigens and tuberculin reactive status in pulmonary tuberculosis. Indian $\mathrm{J}$ Med Res 2000;112:86-92.

25. Soborg C, Madsen HO, Andersen AB, Lillebaek T, KokJensen A, Garred P. Mannose-binding lectin polymorphisms in clinical tuberculosis. J Infect Dis 2003;188:777-82.

26. Ozbas-Gerceker F, Tezcan I, Berkel AI, Ozkara S, Ozcan $A$, Ersoy $F$, et al. The effect of mannose-binding protein gene polymorphisms in recurrent respiratory system infections in children and lung tuberculosis. Turk $\mathrm{J}$ Pediatr 2003;45:95-8.

27. Jamieson SE, Miller EN, Black GF, Peacock CS, Cordell $\mathrm{HJ}$, Howson JM, et al. Evidence for a cluster of genes on chromosome 17q11-q21 controlling susceptibility to tuberculosis and leprosy in Brazilians. Genes Immun 2004;5:46-57.

28. Miller SA, Dykes DD, Polesky HF. A simple salting out procedure for extracting DNA from human nucleated cells. Nucleic Acids Res 1988;16:1215.

29. Johannesen J, Pie A, Pociot F, Kristiansen OP, Karlsen $A E$, Nerup J, et al. Linkage of the human inducible nitric oxide synthase gene to type 1 diabetes. J Clin Endocrinol Metab 2001;86:2792-6.

30. Blackwell JM. Genetics of host resistance and susceptibility to intramacrophage pathogens: A study of multicase families of tuberculosis, leprosy and leishmaniasis in north-eastern Brazil. Int J Parasitol 1998;28:21-8.

31. Tso HW, Lau YL, Tam CM, Wong HS, Chiang AK. Associations between IL12B polymorphisms and tuberculosis in the Hong Kong Chinese population. J Infect Dis 2004;190:913-9.

32. Goldfeld AE. Genetic susceptibility to pulmonary tuberculosis in Cambodia. Tuberculosis 2004;84:76-81.

33. Soborg C, Andersen AB, Madsen HO, Kok-Jensen A, Skinhoj P, Garred P. Natural resistance-associated macrophage protein 1 polymorphisms are associated with microscopy-positive tuberculosis. J Infect Dis 2002;186:517-21.

34. Greenwood CM, Fujiwara TM, Boothroyd LJ, Miller MA, Frappier D, Fanning EA, et al. Linkage of tuberculosis to chromosome 2 q35 loci, including NRAMP1, in a large aboriginal Canadian family. Am J Hum Genet 2000;67:405-16.

35. Bellamy R, Beyers N, McAdam KP, Ruwende C, Gie R, Samaai $P$, et al. Genetic susceptibility to tuberculosis in Africans: A genome-wide scan. Proc Natl Acad Sci USA 2000;97:8005-9.

36. Pospelov LE, Matrakshin AG, Chernousova LN, Tsoi KN, Afanasjev KI, Rubtsova GA, et al. Association of various genetic markers with tuberculosis and other lung diseases in Tuvinian children. Tuber Lung Dis 1996;77:77-80.

Source of Support: The Council for Scientific and Industrial Research, DST and Institute of Molecular Medicine, Conflict of Interest: None declared. 